\title{
Impacts of Alternative Residential Energy Standards- Rural Housing Amendments Study, Phase I
}

Executive Summary
S. Balistocky
A. D. Lee
A. A. Bohn
R. G. Pratt
J. A. Heidell
Z. T. Taylor
P. L. Hendrickson

November 1985

Prepared for the U.S. Department of Energy under Contract DE-AC06-76RLO 1830

Pacific Northwest Laboratory Operated for the U.S. Department of Energy by Battelle Memorial Institute 


\title{
DISCLAIMER
}

This report was prepared as an account of work sponsored by an agency of the United States Government. Neither the United States Government nor any agency thereof, nor any of their employees, makes any warranty, express or implied, or assumes any legal liability or responsibility for the accuracy, completeness, or usefulness of any information, apparatus, product, or process disclosed, or represents that its use would not infringe privately owned rights. Reference herein to any specific commercial product, process, or service by trade name, trademark, manufacturer, or otherwise, does not necessarily constitute or imply its endorsement, recommendation, or favoring by the United States Government or any agency thereof. The views and opinions of authors expressed herein do not necessarily state or reflect those of the United States Government or any agency thereof.

\author{
PACIFIC NORTHWEST LABORATORY \\ operated by \\ BATTELLE \\ for the \\ UNITED STATES DEPARTMENT OF ENERGY \\ under Contract DE-AC06-76RLO 1830
}

\begin{tabular}{|c|c|}
\hline \multicolumn{2}{|c|}{$\begin{array}{c}\text { Printed in the United States of America } \\
\text { Available from } \\
\text { National Technical Information Service } \\
\text { United States Department of Commerce } \\
5285 \text { Port Royal Road } \\
\text { Springfield, Virginia } 22161\end{array}$} \\
\hline \multicolumn{2}{|c|}{$\begin{array}{l}\text { NTIS Price Codes } \\
\text { Microfiche } A 01\end{array}$} \\
\hline \multicolumn{2}{|c|}{ Printed Copy } \\
\hline Pages & $\begin{array}{l}\text { Price } \\
\text { Codes }\end{array}$ \\
\hline $001-025$ & $\mathrm{~A} 02$ \\
\hline $026-050$ & A03 \\
\hline $051-075$ & A04 \\
\hline $076-100$ & $A 05$ \\
\hline $101-125$ & $A 06$ \\
\hline $126-150$ & $\wedge 07$ \\
\hline 151.175 & $\mathrm{~A} 0 \mathrm{~B}$ \\
\hline $176-200$ & $A 09$ \\
\hline $201-225$ & A010 \\
\hline $226-250$ & A011 \\
\hline $251-275$ & $\mathrm{~A} 012$ \\
\hline $276-300$ & A013 \\
\hline
\end{tabular}


IMPACTS OF ALTERNATIVE RESIDENTIAL

ENERGY STANDARDS--RURAL HOUSING

AMENDMENTS STUDY, PHASE 1

EXECUTIVE SUMMARY

S. Balistocky

A. A. Bohn

J. A. Heidell

P. L. Hendrickson

A. D. Lee

R. G. Pratt

Z. T. Taylor

November 1985

Prepared for the U.S. Department of Energy under Contract DE-AC06-76RLO 1830

Pacific Northwest Laboratory

Richland, Washington 99352 

This report summarizes the results of Impacts of Alternative Residential Standards-Rural Housing Amendments Study, Interim Report (PNL-5694). The details of the study are presented in that companion volume. 



\section{CONTENTS}

FOREWORD i i i

INTRODUCTION 1

FEDERAL LEGISLATION AND POLICY BACKGROUND $\ldots \ldots \ldots \ldots \ldots \ldots \ldots \ldots \ldots$

STUDY OBJECTIVES AND SCOPF $\ldots \ldots \ldots \ldots \ldots \ldots \ldots \ldots \ldots \ldots \ldots \ldots \ldots \ldots \ldots$

MANUFACTURED HOUSING CHARACTERISTICS AND ROLE IN THE HOUSING

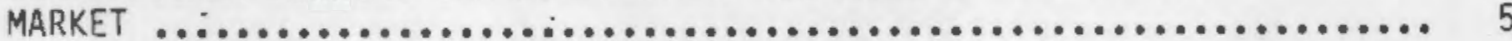

MANUFACTURED HOME DEFINITION ANO OEMOGRAPHICS $\ldots \ldots \ldots \ldots \ldots \ldots \ldots \ldots$

ENERGY CHARACTERISTICS OF MANUFACTURED HOMES $\ldots \ldots \ldots \ldots \ldots \ldots \ldots \ldots$

CHARACTERISTICS OF MANUFACTURED HOME OCCUPANTS $\ldots \ldots \ldots \ldots \ldots \ldots \ldots 7$

COMPARISON OF MEASURED AND SIMULATEO ENERGY CONSUMPTION DATA $\ldots \ldots \ldots .9$

CHARACTERIZATION OF ALTERNATIVE STANDARDS $\ldots \ldots \ldots \ldots \ldots \ldots \ldots \ldots \ldots \ldots \ldots \ldots$

CLIMATE ZONE RELATIONSHIPS BETWEEN STANDARDS $\ldots \ldots \ldots \ldots \ldots \ldots \ldots \ldots . . \ldots$

COMPONENT REQUIREMENTS OF SITE-BUILT ȘTANDARDS $\ldots \ldots \ldots \ldots \ldots \ldots \ldots . . . . . .12$

COMPONENT REOUIREMENTS OF MANUFACTURED HOME STANDARDS $\ldots \ldots \ldots \ldots . . .13$

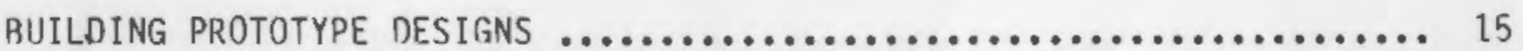

BUILDING PROTOTYPE DESCRIPTIONS $\ldots \ldots \ldots \ldots \ldots \ldots \ldots \ldots \ldots \ldots \ldots \ldots \ldots$

MANUFACTURED HOME COMPLIANCE DESIGNS $\ldots \ldots \ldots \ldots \ldots \ldots \ldots \ldots \ldots \ldots \ldots$

SITE-BUILT HOME CDMPLIANCE DESIGNS $\ldots \ldots \ldots \ldots \ldots \ldots \ldots \ldots \ldots \ldots \ldots$

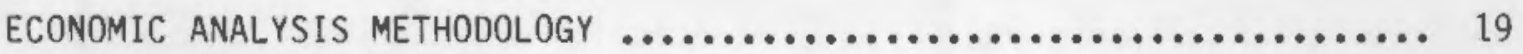

LIFE-CYCLE COST PARAMETERS ......................... 19

ENERGY COST PARAMETERS $\ldots \ldots \ldots \ldots \ldots \ldots \ldots \ldots \ldots \ldots \ldots \ldots \ldots \ldots \ldots \ldots \ldots \ldots \ldots \ldots \ldots \ldots$

CONSTRUCTION COST ESTIMATES ........................... 21

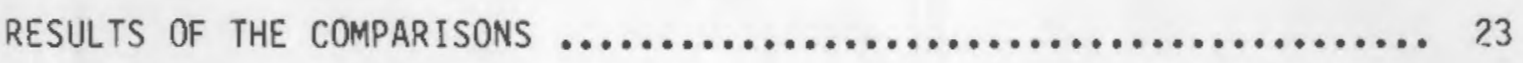

ENERGY REQUIREMENTS $\ldots \ldots \ldots \ldots \ldots \ldots \ldots \ldots \ldots \ldots \ldots \ldots \ldots \ldots \ldots \ldots . \ldots . \ldots . \ldots$

ECONOMIC ANALYSES $\ldots \ldots \ldots \ldots \ldots \ldots \ldots \ldots \ldots \ldots \ldots \ldots \ldots \ldots \ldots \ldots \ldots \ldots$ 
FINDINGS FOR SITE-RUILT HOUSING ...................... 29

FINDINGS FOR MANUFACTURED HOUSING $\ldots \ldots \ldots \ldots \ldots \ldots \ldots \ldots \ldots \ldots \ldots \ldots$

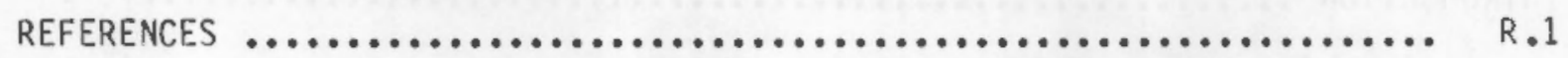




\section{TABLES}

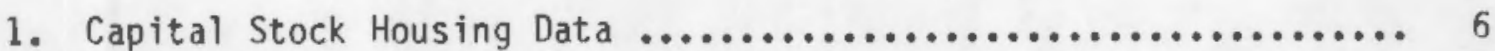

2. Sumnary of Thermal Characteristics, $1982 \ldots \ldots \ldots \ldots \ldots \ldots \ldots .6 . \ldots 6$

3. Housing Energy Consumption Data, April 1982 - March 1983 ....... 7

4. Income Characteristics of Home Occupants $\ldots \ldots \ldots \ldots \ldots \ldots \ldots \ldots . .8$

5. Climate Zone Data $. . . \ldots \ldots \ldots \ldots \ldots \ldots \ldots \ldots \ldots \ldots \ldots \ldots, 11$

6. Summary of Site-Built Standards' Maximum U-Value $\ldots \ldots \ldots \ldots \ldots \ldots, 12$

7. Sumnary of Manufactured Housing Standards' Maximum U-Values ..... 13

8. Manufactured Home Compliance Designs $\ldots \ldots \ldots \ldots \ldots \ldots \ldots \ldots \ldots, \ldots$

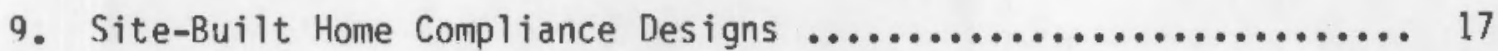

10. Key Economic Parameters .................................. 19

11. Current Utility Rates $\ldots \ldots \ldots \ldots \ldots \ldots \ldots \ldots \ldots \ldots \ldots \ldots \ldots \ldots, 20$

12. FEMP Real Fuel Escalation Rates $\ldots \ldots \ldots \ldots \ldots \ldots \ldots \ldots \ldots \ldots . . . . . .20$

13. Building Loads for Site-Built Homes $\ldots \ldots \ldots \ldots \ldots \ldots \ldots \ldots \ldots . . . . .23$

14. Building Loads for Manufactured Homes $\ldots . . . . . . . . . . . . . . . .24$

15. Summary of Energy and Economic Analys is Results for Single-

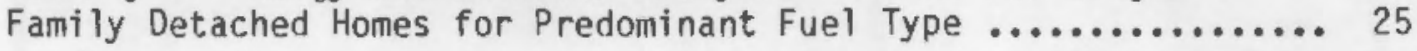

16. Summary of Results for Manufactured Homes--Gas Heating $\ldots . \ldots . .26$

17. Summary of Results for Manufactured Homes--Electric Heating ..... 27 



\section{INTRODUCTION}

Congress, numerous administrations, and federal agencies have long recognized the importance of and need for adequate housing for all families. Recent dramatic rises in housing costs have exacerbated an already serious problem for many low income families. A number of government programs and policies have addressed this issue.

This interim report presents the results of a preliminary study conducted by Pacific Northwest Laboratory (PNL) in response to the Rural Housing Amendments of 1983 (Title $V$ of Public Law 98-181, hereafter referred to as the "Act"). The Act requires the Secretary of Energy to deliver a report to Congress on the impacts of several national energy conservation standards that apply to manufactured housing (mobile homes) and conventional site-built housing. This report discusses the housing market and how these standards affect the overall energy economics of these two housing types.

The results presented in this report are preliminary in nature. Though this study uses an approach that tends to minimize potential distortions caused by modeling assumptions, an important consideration must be recognized: the basic data for the different housing types result from separately developed simulations, so comparisons between housing types must be treated with caution.

\section{FEDERAL LEGISLATION AND POLICY BACKGROUNI}

Historically, the federal government has played a significant role in the national housing market. The U.S. Department of Housing and Urban Development (HUD) administered Federal Housing Administration (FHA) and Veterans' Administration (VA) loan programs with total insurance and loan guarantee funds of $\$ 239$ billion in 1982. The Farmer's Home Administration (FmHA) of the Department of Agriculture (DOA) also administers several billion dollars of loan programs, primarily in rural areas. Until recently, however, neither agency has played a major role in funding the purchase of those manufactured homes comnonly referred to as mobile homes.

In the Act, Congress permitted the Secretary of Agriculture, through FmHA, to include manufactured homes in the agency's Title $V$ subsidized loan program. 
The Act directs FmHA to establish energy conserving requirements for manufactured homes covered under Title $V$. Those requirements must meet two tests: 1) they must be cost-effective over the home's life or term of mortgage, whichever is less, and 2) they must not increase the owner's annual loan payment more than they decrease annual energy expenditures. In the interim period before FmHA issues the new standards, the Act requires manufactured homes to meet the same energy criteria required of other single-family detached (site-built) homes covered under Title $V$.

The Act also directs the U.S. Department of Energy (DOE) to compare the impacts of the FmHA energy standards with those of other federal standards and to compare manufactured housing performance to site-built housing performance. This report presents the preliminary results of Phase 1 of the DOE study. The final DOE report, presenting the results of Phase 2, will await the issuance of FmHA's new standard.

STUDY OBJECTIVES AND SCOPE

The Act requires a study that compares the differential construction costs, actual annual energy use, and the projected value of energy saved over the lifetime of manufactured homes built to standards under Title $V$, with those built to the standards of Titles I and II of the National Housing Act of 1949. (Since Title I applies primarily to home retrofit, it has not been addressed separately.) The Act also requires comparisons with site-built housing built to relevant standards.

The energy impacts of three applicable standards for each housing type have been examined for housing in 13 representative cities. Economic analyses have been conducted for a subset of 6 cities.

Simulated energy consumption data provide the basis for the results presented here. Though no monitored energy consumption data are available for this study, a survey of 1 iterature comparing simulated and monitored data suggests that simulations provide an adequate representation of actual energy requirements. Specifically, these results are based on an extensive DOE energy data base, used in conjunction with a DOE data base of cost estimates for a range of energy conservation options. 
Cost-effectiveness comparisons are based on discounted (net) life-cycle cost. The economic analysis is conducted from the perspective of the "typical" homebuyer. The impacts of federal loan programs on down payments, interest rates, and mortgage terms are not considered. Though this exclusion deviates somewhat from reality, it provides a common base from which to compare different standards and make comparisons across housing types. The final report will include a more thorough treatment of these variables. 

MANUFACTURED HOUSING CHARACTERISTICS AND ROLE IN THE HOUSING MARKET

An understanding of the manufactured housing market and the occupants of manufactured houses is necessary in the assessment of the effects of building standards on those occupants. This section presents relevant background information developed for this assessment.

MANUFACTURED HOME DEFINITIDN AND DEMOGRAPHICS

The Act and this study focus on manufactured homes covered by the HUD Manufactured Home Construction and Safety Standards (MHCSS) appearing in 24 CFR 3280 ("HUD-code" homes). These homes are "transportable in one or more sections . . three hundred twenty or more square feet, and . . built on a permanent chassis." While these homes are commonly called mobile homes, the generic term "manufactured" home also includes modular/sectional houses, panelized houses, and pre-cut houses. Local building codes apply to the last three types, while the HUD standards preemptively cover the mobile homes. Hereafter, the term "manufactured homes" refers only to the HUD-code homes.

Table 1 contains housing stock data for both manufactured and site-built housing. The data suggest that manufactured homes represent a rapidly growing share of the housing stock; they constituted $27 \%$ of new housing starts in 1982 , but only $6 \%$ of the total stock. They are considerably less expensive than site-built homes, both in total cost and in cost per square foot. The distribution of manufactured homes in rural areas and warm climates is higher than that of site-built homes.

Nationally, most (70\% to $75 \%)$ manufactured homes are single-section units. In the West, however, multi-section units are more prevalent $(60 \%$ of homes) than single sections. A typical new single-section unit contains $980 \mathrm{sq} \mathrm{ft}$, and a double-section contains $1152 \mathrm{sq} \mathrm{ft}$.

\section{ENERGY CHARACTERISTICS DF MANUFACTURED HOMES}

Table 2 compares the thermal and fuel use of manufactured and other single-family homes. It is observed that manufactured homes depend almost 
TABLE 1. Capital Stock Housing Data

\begin{tabular}{|c|c|c|}
\hline Parameter & Manufactured Homes & Other Single-Family Homes \\
\hline Homes completed $(a)$ & $\begin{array}{l}236,000(1982) \\
292,000(1983)\end{array}$ & $632,000 \quad(1982)$ \\
\hline $\begin{array}{l}\text { Median sales price of } \\
\text { new home }(1983), \$(b)\end{array}$ & $\$ 20,400$ & $\$ 73,200$ \\
\hline $\begin{array}{l}\text { Average area of exist- } \\
\text { ing units, (Noyember } \\
\text { 1982), sq ft(c) }\end{array}$ & 846 (heated area) & $\begin{array}{c}2,061 \text { (detached homes) } \\
1,717 \text { (heated area) }\end{array}$ \\
\hline $\begin{array}{l}\text { Average stock age } \\
(1982) \text {, years }\end{array}$ & 7.7 & 26.3 \\
\hline $\begin{array}{l}\text { Total stock (1982), } \\
\text { millions }(c)\end{array}$ & 3.7 & 57.7 \\
\hline $\begin{array}{l}\text { Owner occupjed stock } \\
\text { (1982), \% (c) }\end{array}$ & 81 & 83 \\
\hline
\end{tabular}

(a) U.S. Bureau of the Census 1984.

(b) Bus. Trend Analysts 1984.

(c) U.S. EIA 1984a.

TABLE 2. Summary of Thermal Characteristics, 1982 (U.S. EIA 1984a)

\begin{tabular}{|c|c|c|}
\hline Parameter & $\begin{array}{l}\text { Manufactured } \\
\text { Homes }\end{array}$ & $\begin{array}{l}\text { Other } \\
\text { Single-Family } \\
\text { Detached Homes }\end{array}$ \\
\hline Average total area, sq $\mathrm{ft}$ & 860 & 2061 \\
\hline Average heated area, $\mathrm{sq} \mathrm{ft}$ & 846 & 1717 \\
\hline $\begin{array}{l}\text { Main heating fuel, \% } \\
\text { Natural gas } \\
\text { Electricity } \\
\text { LPG } \\
\text { Fuel oil } \\
\text { Other }\end{array}$ & $\begin{array}{l}29.3 \\
23.7 \\
23.8 \\
11.6 \\
11.5\end{array}$ & $\begin{array}{r}56.8 \\
12.9 \\
5.0 \\
12.6 \\
10.6\end{array}$ \\
\hline Central air conditioning, $\%$ & 28.5 & 23.1 \\
\hline Room air conditioning, $\%$ & 29.4 & 26.0 \\
\hline Roof insulated, \% & 66.7 & 67.2 \\
\hline All walls insulated, $\%$ & 73.5 & 51.5 \\
\hline
\end{tabular}


equally on a broader range of fuel types than do site-built homes. Manufactured homes are more likely to have insulated walls, probably because the stock is newer.

Table 3 compares the energy consumption in the two housing types. While manufactured homes compose about $6 \%$ of the housing stock, they consume about $4 \%$ of the energy due to their smaller size. On a per square foot basis, however, manufactured homes consume $30 \%$ more total energy than other single-family homes.

CHARACTERISTICS OF MANUFACTURED HOME OCCUPANTS

Residents of manufactured homes are a diverse group. The ages of about half the occupants are under 30 or over 60 . The median age of the household head ranges from 36 in North Dakota to 59 in Florida. Nationally, the median age is 47 years. About one fourth are retired. The median education level of the household head is 12.2 years.

Table 4 presents information on family income. It is noted that manufactured home occupants generally have lower incomes than occupants of sitebuilt homes. However, more recent buyers of manufactured homes appear to have higher incomes than previous buyers.

TABLE 3. Housing Energy Consumption Data, Apri1 1982 - March 1983 (a)

\begin{tabular}{|c|c|c|}
\hline Parameter & $\begin{array}{l}\text { Manufactured } \\
\text { Homes }\end{array}$ & $\begin{array}{l}\text { Other } \\
\text { Single-Family } \\
\text { Detached Homes }\end{array}$ \\
\hline $\begin{array}{l}\text { Total energy consumption } \\
\text { (quadrillion } \mathrm{Btu} \text { ) }\end{array}$ & 0.27 & 6.04 \\
\hline $\begin{array}{l}\text { Total energy consumption/ } \\
\text { household (million Btu) }\end{array}$ & 72 & 112 \\
\hline $\begin{array}{l}\text { Total energy consumption/ } \\
\text { heated area, sq ft (Btu) }\end{array}$ & 85,100 & 65,200 \\
\hline
\end{tabular}

(a) U.S. EIA $1984 b$. 
TABLE 4. Income Characteristics of Home Occupants

$\begin{array}{cccc}\text { Parameter } & \begin{array}{c}\text { Manufactured } \\ \text { Homes }\end{array} & \begin{array}{c}\text { All Other } \\ \text { Median annual household income, } \$(a)\end{array} & \begin{array}{c}12,000(1980) \\ 14,424(1981)\end{array}\end{array}$

\% occupants with 1981 annual

family income that was:

$<\$ 10,000$

$<\$ 20,000$

$<\$ 30,000$

38

22

$\begin{array}{ll}73 & 47\end{array}$

$92 \quad 81$

$\%$ families earning, more than

$\$ 20,000(1983)(B)$

0ccupant $<3$ years

All occupants

41

33

(a) Bus. Trend Analysts 1984.

(b) U.S. EIA 1984b. 
To evaluate the energy and economic impacts of the various standards, it would be desirable to monitor a number of homes built to each. However, such a task would necessarily involve a very large number of homes to adequately answer the questions raised in the Act. An alternative method of computer simulation can be used if the model is able to accurately predict actual energy requirements.

Very little information is currently available that compares simulated and actual (monitored) energy consumption in manufactured homes. However, the few papers identified, as well as a wealth of information concerning site-built home energy comparisons, indicate that the popular building models are able to predict annual energy requirements within $\$ 20 \%$ for both occupied and unoccupied buildings. This error band tends to be narrower when predicting differential impacts of various constructions than when predicting total annual consumption. Perhaps the area most prone to error is the estimation of air infiltration rates. However, since this study does not address infiltration measures and deals primarily with differential impacts, the accuracy of the simulation data should be sufficient.

The DOE 2.1 building energy analysis model was used to develop the energy data used in this study. The model is quite sophisticated, accounting for many complex phenomena and interactions. Its results generally compare favorably with the $20 \%$ error band noted above. 

CHARACTERIZATION OF ALTERNATIVE STANDARDS

This section briefly discusses the thermal requirements of each building standard analyzed. For site-built homes, the three standards considered are the HUD Minimum Property Standards (MPS); the FmHA Title V standard; and the American Society of Heating, Refrigerating, and Air Conditioning Engineers ' (ASHRAE) Standard 90A-80. The three standards applied to manufactured homes are the HUD Title VI standard (MHCSS), the HUD Title II-E standard (used for HUO's Title II loan program) and the FmHA Title $V$ standard. While the FmHA standard is currently common to both housing types, this may change upon FmHA's issuance of a new manufactured housing standard if it differs from the current Title $\vee$ standard.

CLIMATE ZONE RELATIONSHIPS BETWEEN STANDARDS

Table 5 lists the 13 cities included in this study, along with the applicable climate zones for each standard. Also listed are annual heating (HDD) and cooling degree days (CDD) (base $65^{\circ} \mathrm{F}$ ). Note that the HUD zones are

TARLE 5. Climate Zone Data

\begin{tabular}{|c|c|c|c|c|c|c|}
\hline City & $\begin{array}{c}\text { HDD } \\
\text { (Base } \\
\left.65^{\circ} \mathrm{F}\right) \\
\end{array}$ & $\begin{array}{l}\text { CDD } \\
\text { (Base } \\
65^{\circ} \mathrm{F} \text { ) } \\
\end{array}$ & $\begin{array}{l}\text { HUD } \\
\text { Title VI } \\
\text { Zone } \\
\end{array}$ & $\begin{array}{l}\text { HuD } \\
\text { Title II-E } \\
\text { Zone } \\
\end{array}$ & $\begin{array}{l}\text { FmHA } \\
\text { Zone }\end{array}$ & $\begin{array}{l}\text { HUD MPS } \\
\text { Zone }\end{array}$ \\
\hline Phoenix & 1765 & 3334 & I & I & 2 & 1 \\
\hline Fort Worth & 2405 & 2500 & I & I & 2 & 1 \\
\hline Fresno & 2611 & 1639 & I & I & 3 & 1 \\
\hline Atlanta & 2961 & 1469 & I & I & 3 & 2 \\
\hline Nashville & 3578 & 1496 & I & I & 3 & 2 \\
\hline Washington, D.C. & 4224 & 1491 & II & II & 3 & 2 \\
\hline Albuquerque & 4348 & 1345 & I & I & 3 & 2 \\
\hline Louisville & 4660 & 1236 & II & II & 4 & 5 \\
\hline New York & 4871 & 1027 & II & II & 4 & 3 \\
\hline Boston & 5634 & 674 & II & II & 4 & 3 \\
\hline Salt Lake City & 6052 & 958 & I I & II & 5 & 3 \\
\hline Cleveland & 6351 & 613 & II & II & 5 & 3 \\
\hline Minneapolis & 8382 & 894 & II & I I I & 5 & 4 \\
\hline
\end{tabular}


geographically based, whereas the other standards use climate (degree days) to define zones. The ASHRAE standard is not included in the table because, rather than defining explicit zones, its requirements are direct functions of climate variables (degree days).

\section{COMPONENT REQUIREMENTS OF SITE-BUILT STANDARDS}

Table 6 summarizes the requirements of the site-built home standards. Again, the ASHRAE standard does not appear in the table because its requirements are continuous functions of climate variables. The ASHRAE standard also differs in that it requires consideration of framing members in calculation of component U-values, while the other two standards do not. Therefore, direct comparison of the standards' requirements is not possible. Meaningful comparisons require the specification of prototype designs, as was done in this study.

TABLE 6. Summary of Site-Built Standards' Maximum U-Values(a)

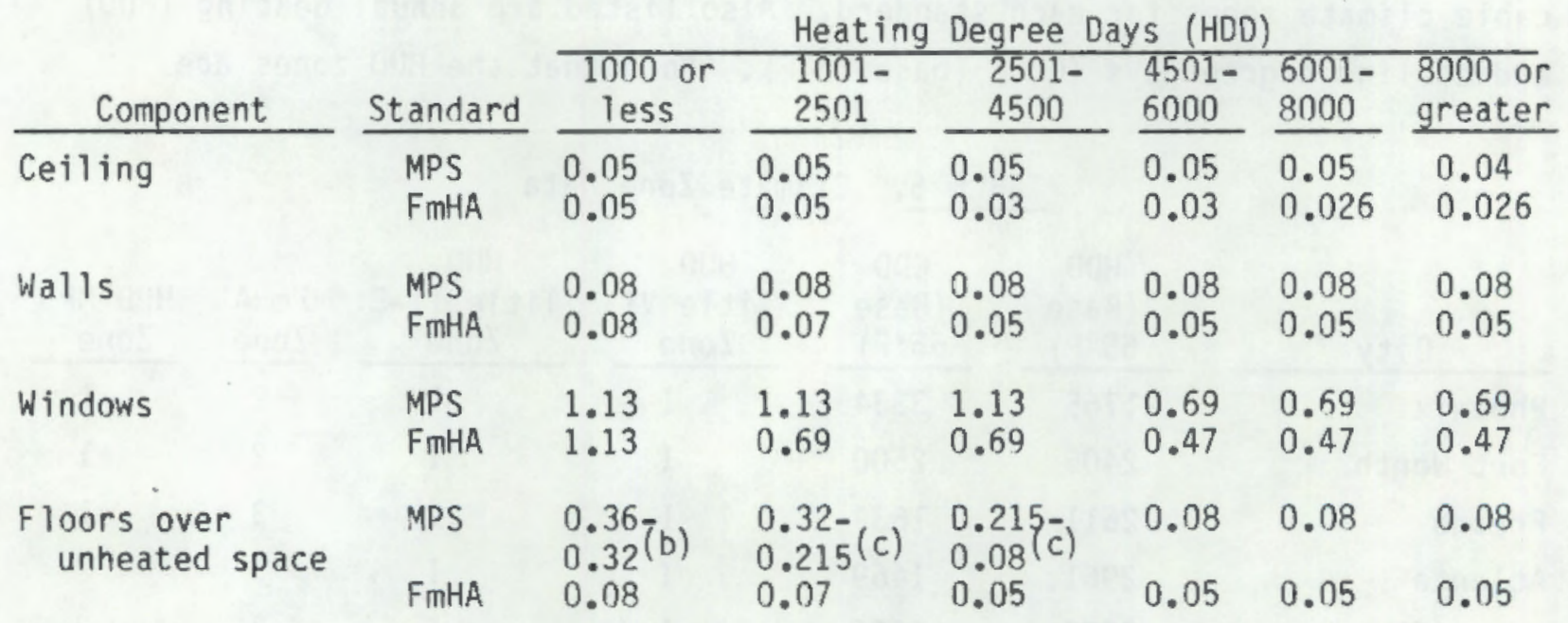

(a) The ASHRAE standard is not shown because it depends directly on HDD rather than climate zone ranges.

(b) U-value is 0.36 for 0 to $500 / \mathrm{HDD}$; between 500 and $1000 \mathrm{HDD}$, interpolate between figures in table.

(c) Interpolate U-values for heating degree days within range in column heading. 
All three standards either require or allow the use of ASHRAE procedures for calculating heat loss and gain.

Only the ASHRAE 90A-80 standard requires air infiltration heat loss calculations or specific heating equipment efficiencies. However, the three standards do not differ significantly in construction requirements that affect air infiltration rates.

\section{COMPONENT REQUIREMENTS OF MANUFACTURED HOME STANDARDS}

Table 7 summarizes the requirements of the HUD Title VI and Title II-E standards. The requirements of the FmHA standard are identical to those listed in Table 6 for site-built homes. Only the FmHA standard specifies component requirements. The HUD standards allow more design flexibility by specifying only an overall building U-value (calculated as the weighted average of component U-values). One exception involves windows, which must be, at a minimum, double paned (or single paned with additional storm windows).

A11 three standards allow ASHRAE procedures for heat loss and gain calculations. The HUD standards require consideration of framing in U-value calculations. Both HUD standards also require air infiltration calculations, while only the Title VI standard specifies heating system efficiencies.

TABLE 7. Summary of Manufactured Housing Standards' Maximum U-Values (a)

\begin{tabular}{|c|c|c|}
\hline Zone & Title VI & Title II-E \\
\hline I & 0.157 & 0.145 \\
\hline$I^{(b)}$ & 0.126 & 0.099 \\
\hline III ${ }^{(b)}$ & 0.104 & 0.087 \\
\hline
\end{tabular}

(a) The FmHA Title $V$ standard requirements used appear in Table 6.

(b) Note that the definition of Zones II and III are different for these two standards. 


\section{BUILDING PROTOTYPE DESIGNS}

To compare the impacts of the various standards, prototype buildings are specified with thermal integrity levels equivalent to those required by each standard. This section discusses the methodology and assumptions used in designing the prototypes.

\section{BUILDING PROTOTYPE DESCRIPTIONS}

Two generic prototypes are used in this analysis. The first is a singlestory, ranch style, single-family detached house. The other is a single-section manufactured house. Both of these prototypes were used in the development of the energy data base for $O O E$ under the Building Energy Performance Standards Program (BEPS).

The site-built prototype contains $1540 \mathrm{sq} f t$ of conditioned floor area. Glazing is equivalent to $15 \%$ of gross floor area. The manufactured prototype contains 902 sq ft of floor area, with windows composing roughly $11 \%$ of that amount.

These prototype designs are modified to meet each standard. The modifications are based on two criteria: 1) acceptability of the design as reasonable building practice and 2) lowest first cost where two or more designs would satisfy the standard. Since all the standards are either vague or roughly equivalent in their infiltration control requirements or have no specific requirements, infiltration differences are not considered. The design options available include roof and ceiling insulation, wall insulation, floor insulation, and window type.

MANUFACTURED HOME COMPLIANCE DESIGNS

Table 8 summarizes the manufactured home configurations designed to comply with the applicable standards. Since the HUD standards allow considerable design latitude, the selected designs represent the least first-cost combinations that satisfy the standards, though it is noted that the required overall $\mathrm{U}$-value could be obtained at lower cost if single-pane windows were allowed in Zone II. 
TABLE 8. Manufactured Home Compliance Designs

\begin{tabular}{|c|c|c|c|c|c|}
\hline City & Standard & $\begin{array}{c}\text { Roof Insul. } \\
\text { R-value } \\
\end{array}$ & $\begin{array}{c}\text { Wall Insul. } \\
\text { R-value } \\
\end{array}$ & $\begin{array}{l}\text { Windows/ } \\
\text { Sash(a) } \\
\end{array}$ & $\begin{array}{c}\text { Floor Insul } \\
\text { R-value }\end{array}$ \\
\hline \multirow[t]{3}{*}{ Phoenix } & $\mathrm{FmHA}$ & R22 & R19 & 2,AL & $\mathrm{R} 11$ \\
\hline & Title VI & R 7 & R 7 & $1, \mathrm{AL}$ & R 7 \\
\hline & Title IIE & R 7 & R11 & $1, \mathrm{AL}$ & R 7 \\
\hline \multirow[t]{3}{*}{ Fort Worth } & FmHA & R22 & R19 & $2, \mathrm{AL}$ & $\mathrm{R} 11$ \\
\hline & Title VI & R 7 & R 7 & $1, \mathrm{AL}$ & R 7 \\
\hline & Title IIE & R 7 & R11 & $1, \mathrm{AL}$ & R 7 \\
\hline \multirow[t]{3}{*}{ Fresno } & $\mathrm{FmHA}$ & R30 & R19 & $2, \mathrm{AL}$ & R19 \\
\hline & Title VI & R 7 & R 7 & $1, \mathrm{AL}$ & R 7 \\
\hline & Title IIE & R 7 & R11 & $1, \mathrm{AL}$ & R 7 \\
\hline \multirow[t]{3}{*}{ Atlanta } & FmHA & R30 & R19 & $2, \mathrm{AL}$ & R19 \\
\hline & Title VI & R 7 & R 7 & $1, \mathrm{AL}$ & R 7 \\
\hline & Title IIE & R 7 & R11 & $1, \mathrm{AL}$ & R 7 \\
\hline \multirow[t]{3}{*}{ Nashville } & FmHA & R30 & R19 & $2, \mathrm{AL}$ & R19 \\
\hline & Title VI & R 7 & R 7 & $1, \mathrm{AL}$ & R 7 \\
\hline & Title IIE & R 7 & R11 & $1, \mathrm{AL}$ & R 7 \\
\hline \multirow[t]{3}{*}{ Washington, D.C. } & FmHA & $\mathrm{R} 30$ & R19 & $2, \mathrm{AL}$ & $\mathrm{R} 19$ \\
\hline & Title VI & R 7 & R11 & $2, \mathrm{AL}$ & R 7 \\
\hline & Title IIE & R19 & R11 & $2, \mathrm{AL}$ & R19 \\
\hline \multirow[t]{3}{*}{ Albuquerque } & $\mathrm{FmHA}$ & $\mathrm{R} 30$ & $\mathrm{R} 19$ & $2, \mathrm{AL}$ & R19 \\
\hline & Title VI & R 7 & R 7 & $1, \mathrm{AL}$ & R 7 \\
\hline & Title IIE & R 7 & R11 & $1, \mathrm{AL}$ & R 7 \\
\hline \multirow[t]{3}{*}{ Louisville. } & FmHA & R30 & R19 & $3, \mathrm{AL}$ & R19 \\
\hline & Title VI & R 7 & R11 & $2, \mathrm{AL}$ & R 7 \\
\hline & Title IIE & R19 & R11 & $2, \mathrm{AL}$ & R19 \\
\hline \multirow[t]{3}{*}{ New York } & $\mathrm{FmHA}$ & R30 & R19 & $3, \mathrm{AL}$ & R19 \\
\hline & Title VI & R 7 & R11 & $2, A L$ & R 7 \\
\hline & Title IIE & R19 & R11 & $2, \mathrm{AL}$ & $\mathrm{R} 19$ \\
\hline \multirow[t]{3}{*}{ Boston } & FmHA & R30 & R19 & $3, \mathrm{AL}$ & R19 \\
\hline & Title VI & R 7 & R11 & $2, \mathrm{AL}$ & R 7 \\
\hline & Title IIE & R19 & R11 & $2, \mathrm{AL}$ & R19 \\
\hline \multirow[t]{3}{*}{ Salt Lake City } & $F_{m H A}(b)$ & R33 & R24 & $3, \mathrm{AL}$ & R19 \\
\hline & Title VI & R 7 & R11 & 2, $\mathrm{AL}$ & R 7 \\
\hline & Title IIE & R19 & R11 & $2, \mathrm{AL}$ & R19 \\
\hline \multirow[t]{3}{*}{ Clevel and } & $F_{m H A}(b)$ & R33 & R24 & $3, \mathrm{AL}$ & R19 \\
\hline & Title VI & R11 & R11 & $2, \mathrm{AL}$ & R17 \\
\hline & Title IIE & R19 & R11 & $2, \mathrm{AL}$ & R19 \\
\hline \multirow[t]{3}{*}{ Minneapol is } & $F_{m H A}(b)$ & R33 & R24 & $3, \mathrm{AL}$ & R19 \\
\hline & Title VI & R11 & R11 & $2, \mathrm{AL}$ & R 7 \\
\hline & Title IIE & $\mathrm{R} 14$ & R19 & $2, \mathrm{AL}$ & $\mathrm{R} 11$ \\
\hline
\end{tabular}

(a) Number of glazings and sash type (AL = aluminum, and AL/TB = aluminum with thermal break).

(b) Though R33 does not meet the FmHA roof requirements for Region 5 , it is the highest $R$-value available in the data base. To compensate, the wall $R$-value was increased from the required $R-19$ to $R-24$, resulting in a similar overall envelope U-value. 
SITE-BUILT HOME COMPLIANCE DESIGNS

Table 9 summarizes the site-built home configurations designed to comply with the relevant standards.

TABLE 9. Site-Built Home Compliance Designs

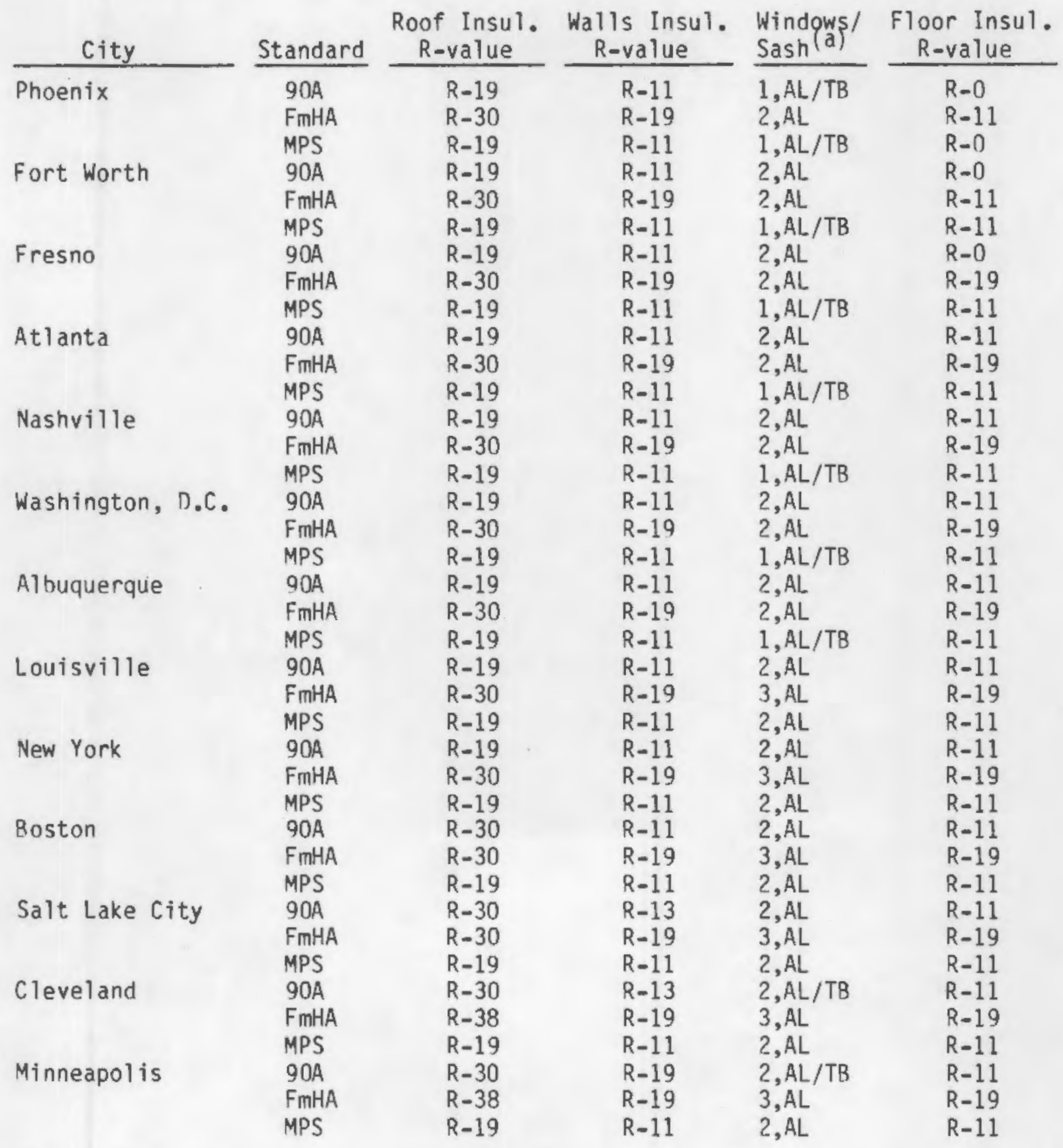

(a) Number of glazings and sash type ( $\mathrm{AL}=$ aluminum, and $\mathrm{AL} / \mathrm{TB}=$ aluminum with thermal break). 



\section{ECONOMIC ANALYSIS METHODOLOGY}

The various standards applicable to each prototype are compared in this report for their impacts on the discounted life-cycle cost of the home from the perspective of the homeowner. Also compared are their impacts on first-year incremental cash flows. These economic criteria appear in the Rural Housing Amendments as requirements for the new FmHA manufactured-home standard.

To make comparisons of -incremental impacts, a baseline must be assumed that represents common minimum building practices. For site-built homes, the ASHRAE 90A-80 standard is considered the base. For manufactured homes, the HUD Title VI standard (MHCSS) is considered the base.

\section{LIFE-CYCLE COST PARAMETERS}

The life-cycle cost calculations are conducted in conformance with the DOE Federal Energy Management Program (FEMP) guidelines of March 1984. Table 10 lists the key economic parameters and their assumed values.

\section{ENERGY COST PARAMETERS}

All initial energy costs were obtained by direct query of the suppliers in each city analyzed. The costs include all applicable taxes and adjustments. A11 heating costs are assumed to occur at the quoted winter rates, and cooling costs at summer rates. Where utilities have block rate structures, the

\section{TABLE 10. Key Economic Parameters}

\begin{tabular}{lc}
\multicolumn{1}{c}{ Parameter } & Value or Source \\
\cline { 1 - 1 } Real discount rate, $\%$ & 10 \\
Nominal mortgage interest rate, $\%$ & 13 \\
Annual inflation rate, $\%$ & 5 \\
Length of loan, years & 30 \\
Down payment on loan, $\%$ & 20 \\
Initial energy costs & Utility rates \\
Real fuel escalation rates & FEMP, March 1984
\end{tabular}


appropriate rate is selected from the highest block in which a typical residence is likely to operate. These selections are based on average fuel bill data obtained from the U.S. Energy Information Agency (EIA). Table 11 presents the initial energy prices used in the analyses.

Fuel escalation (real) rates are taken from FEMP 1984 estimates for the appropriate regions of interest. These are presented in Table 12.

TABLE 11. Current Utility Rates, \$/MMBtu

\begin{tabular}{|c|c|c|c|c|}
\hline \multirow[b]{2}{*}{ City } & \multicolumn{2}{|c|}{ Electricity } & \multirow[b]{2}{*}{ Gas } & \multirow{2}{*}{$\begin{array}{l}\text { Fuel } \\
0 i 1 \\
\end{array}$} \\
\hline & Summer & Winter & & \\
\hline Phoenix & 27.8950 & 20.0171 & 5.132 & \\
\hline Atlanta & 17.3530 & 17.2586 & 5.793 & \\
\hline Nashville & 12.9722 & 12.9722 & 5.124 & \\
\hline Washington, D.C. & $17.8144^{(a)}$ & $17.8144^{(a)}$ & 7.895 & \\
\hline Boston & 24.4591 & 15.6692 & 6.692 & 8.2846 \\
\hline Minneapolis & 18.2392 & 15.7534 & 5.612 & \\
\hline
\end{tabular}

(a) Prices for homes not having electric heating. Homes with electric heating, hot water, and air conditioning pay $\$ 18.5909$ summer and winter.

TABLE 12. FEMP Real Fuel Escalation Rates, \%/year

\begin{tabular}{|c|c|c|c|c|}
\hline City & Fue1 & $1985-1990$ & $1990-1995$ & $1995-2000$ \\
\hline \multirow[t]{2}{*}{ Phoenix } & Electric & 2.42 & 2.76 & 3.60 \\
\hline & Gas & 6.27 & 8.72 & 1.54 \\
\hline \multirow[t]{2}{*}{ Nashville/Atlanta } & Electric & 1.47 & 2.40 & 3.45 \\
\hline & Gas & 5.46 & 9.56 & 1.54 \\
\hline \multirow[t]{2}{*}{ Washington, D.C. } & Electric & 1.38 & 2.45 & 3.47 \\
\hline & Gas & 4.02 & 9.36 & 1.54 \\
\hline \multirow[t]{3}{*}{ Boston } & Electric & 2.79 & 2.37 & 3.44 \\
\hline & $0 i 1$ & 7.49 & 8.09 & 1.39 \\
\hline & Gas & 4.82 & 8.98 & 1.54 \\
\hline \multirow[t]{2}{*}{ Minneapol is } & Electric & 0.35 & 2.47 & 3.48 \\
\hline & Gas & 5.41 & 9.11 & 1.54 \\
\hline
\end{tabular}


The estimates used here for conservation option cost differentials are based on data developed for DOE by Steven Winter Associates. The manufactured housing cost data represent costs to the manufacturer, while site-built data represent contractor costs. To estimate final consumer costs, the manufactured home costs are multiplied by a factor of 2.22 , provided by HUD officials. Site-built data base costs are multiplied by a factor of 1.22 , based on information supplied by the National Association of Home Builders. A national average sales tax of $3.25 \%$ is also added to the costs for both housing types. The resulting costs are further adjusted by 1984 Means regional construction cost multipliers. 



\section{RESULTS OF THE COMPARISONS}

\section{ENERGY REQUIREMENTS}

The results of the energy use comparisons are presented in Table 13 for site-built housing and in Table 14 for manufactured housing. The energy use numbers represent overall annual space conditioning loads unadjusted for equipment efficiencies. In this form, the data are of 1 imited use. However, some useful observations are possible. For site-built homes, the FmHA standard is more stringent than the base case (ASHRAE 90A-80). With a few exceptions, the MPS standard is less stringent than the base. For manufactured homes, both the FmHA and HUD Title II-E standards are more strict than the base case HUD Title VI standard.

The reader is cautioned that direct comparisons between manufactured and site-built housing using these tables are not possible. The data originate from two separately conducted simulations, with different assumptions regarding internal heat gains, orientation, glazing area and distribution, etc.

TABLE 13. Building Loads for Site-Built Homes, MMBtu/yr

\begin{tabular}{|c|c|c|c|c|c|c|}
\hline \multirow[b]{2}{*}{ City } & \multicolumn{2}{|c|}{ ASHRAE $90 A-80$} & \multicolumn{2}{|c|}{ MPS } & \multicolumn{2}{|c|}{$\mathrm{FmHA}$} \\
\hline & Heating & Cooling & Heating & Cooling & Heating & Cooling \\
\hline Phoenix & 26.59 & 81.04 & 26.59 & 81.04 & 14.72 & 56.86 \\
\hline Fort Worth & 40.95 & 57.04 & 31.45 & 48.63 & 26.01 & 44.29 \\
\hline Fresno & 47.75 & 43.92 & 36.14 & 32.46 & 25.83 & 26.04 \\
\hline Atlanta & 35.77 & 24.56 & 40.90 & 25.44 & 29.55 & 22.44 \\
\hline Nashville & 43.94 & 26.18 & 50.07 & 27.58 & 36.54 & 24.04 \\
\hline Washington, D.C. & 53.18 & 25.09 & 59.45 & 26.69 & 44.15 & 22.76 \\
\hline Albuquerque & 45.05 & 18.40 & 51.19 & 19.54 & 36.59 & 15.86 \\
\hline Louisville & 56.84 & 21.92 & 56.84 & 21.92 & 44.29 & 19.36 \\
\hline New York & 59.51 & 14.82 & 59.51 & 14.82 & 45.91 & 13.07 \\
\hline Boston & 72.27 & 9.52 & 75.84 & 9.90 & 58.63 & 8.47 \\
\hline Salt Lake City & 70.06 & 14.74 & 74.73 & 15.44 & 56.24 & 12.57 \\
\hline Clevel and & 72.81 & 8.49 & 81.01 & 8.87 & 61.18 & 7.30 \\
\hline Minneapol is & 98.09 & 14.21 & 144.51 & 15.00 & 87.07 & 12.78 \\
\hline
\end{tabular}


TABLE 14. Building Loads for Manufactured Homes, MMBtu/yr

\begin{tabular}{|c|c|c|c|c|c|c|}
\hline \multirow[b]{2}{*}{ City } & \multicolumn{2}{|c|}{ Title VI } & \multicolumn{2}{|c|}{ Title II-E } & \multicolumn{2}{|c|}{$\mathrm{FmHA}$} \\
\hline & Heating & Cooting & Heating & Cooling & Heating & Cooling \\
\hline Phoenix & 17.793 & 42.583 & 17.134 & 41.393 & 9.292 & 34.575 \\
\hline Fort Worth & 25.906 & 29.595 & 24.954 & 29.017 & 14.120 & 25.802 \\
\hline Fresno & 30.889 & 22.773 & 29.758 & 22.149 & 14.259 & 18.185 \\
\hline Atlanta & 28.834 & 16.313 & 27.625 & 15.970 & 15.860 & 14.386 \\
\hline Nashville & 34.422 & 17.699 & 33.033 & 17.346 & 19.114 & 15.662 \\
\hline Washington, D.C. & 36.146 & 14.924 & 27.029 & 14.676 & 22.487 & 14.628 \\
\hline Albuquerque & 38.261 & 15.018 & 36.655 & 14.607 & 20.173 & 12.012 \\
\hline Louisville & 39.109 & 13.985 & 32.399 & 13.964 & 23.187 & 12.914 \\
\hline New York & 40.284 & 9.009 & 30.195 & 9.221 & 23.529 & 8.668 \\
\hline Boston & 51.275 & 6.324 & 38.786 & 6.399 & 30.443 & 6.107 \\
\hline Salt Lake City & 53.202 & 12.059 & 39.994 & 11.599 & 31.246 & 10.524 \\
\hline Clevel and & 52.232 & 5.846 & 41.751 & 6.159 & 33.114 & 5.584 \\
\hline Minneapolis & 73.725 & 10.010 & 59.391 & 9.501 & 45.067 & 9.258 \\
\hline
\end{tabular}

ECONOMIC ANALYSES

The results of the energy and economic comparisons for six cities are summarized in Table 15 for site-built homes, and Tables 16 and 17 for manufactured homes with gas and electric heating, respectively. Note that a negative change in life-cycle cost indicates a net benefit to the homebuyer, while a negative change in cash flow represents higher first-year costs to the buyer. The internal rate of return (IRR) is included as an indication of the sensitivity of the results to changes in the discount rate. Large IRRs (about $15 \%$ or more) suggest that the conservation investment is not very sensitive to reasonable variations in the discount rate.

The energy values given represent annual building loads adjusted for seasonal equipment efficiencies. Gas and fuel oil heating are assumed to be $69 \%$ efficient on a seasonal basis. Electric resistance heating is assumed to be $100 \%$ efficient. Seasonal coefficients of performance (COP) for heat pumps are varied according to $c l$ imate; all air conditioning is assumed to have a seasonal COP of 2.28. Again, the energy results should be viewed with caution, since 
TARLE 15. Summary of Energy and Economic Analysis Results for Single-Family Detached Homes for Predominant Fuel Type ${ }^{(a)}$

\begin{tabular}{|c|c|c|c|c|c|c|c|}
\hline Characteristics & Standard & $\begin{array}{c}\text { Wash inqton, } \\
\text { D.C. } \\
\end{array}$ & Phoen Ix & Minneapolis & Boston & AtIanta & Nashville \\
\hline $\begin{array}{c}\text { Energy use, } \\
\text { MMBtu/yr }\end{array}$ & $\begin{array}{l}\text { ASHRAE } \\
\text { MPS } \\
\text { FmHA }\end{array}$ & $\begin{array}{l}41.22 \\
45.48 \\
35.07\end{array}$ & $\begin{array}{l}50.21 \\
50.21 \\
33.04\end{array}$ & $\begin{array}{l}148.40 \\
172.54 \\
131.80\end{array}$ & $\begin{array}{r}108.91 \\
114.25 \\
88.70\end{array}$ & $\begin{array}{l}62.62 \\
70.44 \\
52.67\end{array}$ & $\begin{array}{l}36.45 \\
40.54 \\
31.31\end{array}$ \\
\hline $\begin{array}{l}\text { Energy use, } \\
\text { kBtu/sq } \mathrm{ft} / \mathrm{yr}\end{array}$ & $\begin{array}{l}\text { ASHRAE } \\
\text { MPS } \\
\text { FmHA }\end{array}$ & $\begin{array}{l}26.77 \\
29.53 \\
22.77\end{array}$ & $\begin{array}{l}32.60 \\
32.60 \\
21.45\end{array}$ & $\begin{array}{r}110.21 \\
112.04 \\
85.58\end{array}$ & $\begin{array}{l}70.72 \\
74.19 \\
57.58\end{array}$ & $\begin{array}{l}40.66 \\
45.74 \\
34.20\end{array}$ & $\begin{array}{l}23.67 \\
26.33 \\
20.33\end{array}$ \\
\hline $\begin{array}{l}\text { Change in } \\
\text { eneray use, } \\
\text { MuBtu/yr }\end{array}$ & $\begin{array}{l}\text { MPS v5 ASHRAE } \\
\text { FmHA vs ASHRAE }\end{array}$ & $\begin{array}{r}4.26 \\
-6.15\end{array}$ & $\begin{array}{r}0.00 \\
-17.17\end{array}$ & $\begin{array}{r}24.14 \\
-16.60\end{array}$ & $\begin{array}{r}5.34 \\
-20.21\end{array}$ & $\begin{array}{r}7.82 \\
-9.95\end{array}$ & $\begin{array}{r}4.09 \\
-5.14\end{array}$ \\
\hline $\begin{array}{l}\text { Change in } \\
\text { energy use, } \\
k B+u / s q \mathrm{ft} / \mathrm{yr}\end{array}$ & $\begin{array}{l}\text { MPS vs ASHRAE } \\
\text { FmHA vs ASHRAE }\end{array}$ & $\begin{array}{r}2.77 \\
-3.99\end{array}$ & -11.15 & $\begin{array}{r}15.68 \\
-10.78\end{array}$ & $\begin{array}{r}3.47 \\
-13.12\end{array}$ & $\begin{array}{r}5.08 \\
-6.46\end{array}$ & $\begin{array}{r}2.66 \\
-3.34\end{array}$ \\
\hline $\begin{array}{c}\text { Change in first } \\
\text { cost, } 19855\end{array}$ & $\begin{array}{l}\text { MPS vS ASHRAE } \\
\text { FmHA vS ASHRAE }\end{array}$ & $\begin{array}{l}-464.57 \\
1849.88\end{array}$ & $\begin{array}{r}0.00 \\
2181.22\end{array}$ & $\begin{array}{r}-1804.34 \\
1010.49\end{array}$ & $\begin{array}{r}-1252.97 \\
1259.29\end{array}$ & $\begin{array}{l}-464.57 \\
1849.89\end{array}$ & $\begin{array}{l}-464.57 \\
1849.89\end{array}$ \\
\hline $\begin{array}{l}\text { Change in first } \\
\text { cost, 1985s/ } \\
\text { sq } \mathrm{ft} / \mathrm{yr}\end{array}$ & $\begin{array}{l}\text { MPS vs ASHRAE } \\
\text { FmHA vS ASHRAE }\end{array}$ & $\begin{array}{r}-0.30 \\
1.20\end{array}$ & $\begin{array}{l}0.00 \\
1.42\end{array}$ & $\begin{array}{r}-1.17 \\
0.66\end{array}$ & $\begin{array}{r}-0.81 \\
0.82\end{array}$ & $\begin{array}{r}-0.30 \\
1.20\end{array}$ & $\begin{array}{r}-0.30 \\
1.20\end{array}$ \\
\hline $\begin{array}{l}\text { Change in } 11 \text { fe- } \\
\text { cycle cost, } \\
19855\end{array}$ & $\begin{array}{l}\text { MPS vS ASHRAE } \\
\text { FMHA vS ASHRAE }\end{array}$ & $\begin{array}{l}536.95 \\
247.46\end{array}$ & $\begin{array}{r}0.00 \\
-3414.67\end{array}$ & $\begin{array}{r}503.54 \\
-605.93\end{array}$ & $\begin{array}{r}-454.08 \\
-1640.02\end{array}$ & $\begin{array}{l}392.67 \\
472.52\end{array}$ & $\begin{array}{l}282.87 \\
594.10\end{array}$ \\
\hline $\begin{array}{l}\text { Change in } \\
\text { first-year } \\
\text { cash flow, } \\
19858\end{array}$ & $\begin{array}{l}\text { MPS vS ASHRAE } \\
\text { FMHA vS ASHRAE }\end{array}$ & $\begin{array}{l}-29.30 \\
-84.61\end{array}$ & $\begin{array}{r}0.00 \\
186.82\end{array}$ & $\begin{array}{r}65.62 \\
-14.01\end{array}$ & $\begin{array}{r}101.12 \\
26.33\end{array}$ & $\begin{array}{r}-2.46 \\
-120.00\end{array}$ & $\begin{array}{r}-8.88 \\
-109.54\end{array}$ \\
\hline
\end{tabular}

(a) Predominant fuel type is heat pump In Phoenix and Minneapolis, fuel ofl in Boston, and gas in Atlanta and Nashville.

they represent total site energy consumption for space conditioning, and there is no distinction between heating and cooling energy use. The economic results, however, incorporate all relevant factors and should be representative of actual impacts in the cities cited.

Some important observations are possible. From Table 15, the MPS, generally a less strict standard than the ASHRAE standard, results in a higher lifecycle cost in all cities except Boston. The FmHA standard, generally more stringent, decreases life-cycle cost in Boston, Minneapolis, and Phoenix, and increases it in the others. Note that these three cities are at the extremes of the climate range. Whether these results indicate a climate inequity cannot be concluded without further examination of sensitivities to other regionally varying parameters. 
Table 16. Summary of Results for Manufactured Homes--Gas Heating

\begin{tabular}{|c|c|c|c|c|c|c|c|}
\hline CharacterIstics & Standard & $\begin{array}{l}\text { ashington, } \\
\text { D.C. }\end{array}$ & Phoen Ix & Minneapol is & Boston & Atlanta & Nashville \\
\hline \multirow{2}{*}{$\begin{array}{l}\text { Change In } \\
\text { energy use, } \\
\text { MMBtu/yr }\end{array}$} & \multirow{2}{*}{ 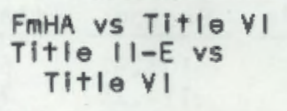 } & & & -41.86 & & -19.65 & -23.08 \\
\hline & & -13.32 & -1.48 & -21.00 & -18.07 & -1.90 & -2.17 \\
\hline \multirow{2}{*}{$\begin{array}{l}\text { Change in } \\
\text { energy use, } \\
\mathrm{kBtu} / \mathrm{sq} \mathrm{ft} / \mathrm{yr}\end{array}$} & \multirow{2}{*}{$\begin{array}{l}\text { FmHA vs TItle VI } \\
\text { TItle II-E vs } \\
T I+1 e \text { VI }\end{array}$} & & -17.55 & & -33.58 & & \\
\hline & & -14.77 & -1.64 & -23.28 & -20.03 & -2.11 & -2.40 \\
\hline \multirow[t]{2}{*}{$\begin{array}{c}\text { Change in first } \\
\text { cost, } 19855\end{array}$} & \multirow{2}{*}{$\begin{array}{l}\text { FmHA vs } T i+l e V I \\
T I+l e \text { II-E vs } \\
\text { TItle VI }\end{array}$} & 1455.96 & 1334.09 & 2901.91 & 2076.78 & 1735.82 & 1735.82 \\
\hline & & 575.09 & 81.64 & 804.45 & 575.09 & 81.64 & 81.64 \\
\hline \multirow{2}{*}{$\begin{array}{l}\text { Change in first } \\
\text { cost, 1985\$/ } \\
\text { sq ft }\end{array}$} & \multirow{2}{*}{$\begin{array}{l}\text { FinA vs } T i+l e V I \\
T i+l e I I-E \text { vs } \\
T I+I \theta V I\end{array}$} & 1.61 & 1.48 & 3.22 & 2.30 & 1.92 & 1.92 \\
\hline & & 0.64 & 0.09 & 0.89 & 0.64 & 0.09 & 0.09 \\
\hline \multirow{2}{*}{$\begin{array}{l}\text { Change in Iife } \\
\text { cycle cost, } \\
1985 \$\end{array}$} & \multirow{2}{*}{$\begin{array}{l}\text { FmHA vs TItIe VI } \\
T I+l_{e} \mid I-E \text { vs } \\
\text { TItIe VI }\end{array}$} & -1070.58 & -1026.83 & -970.68 & -1309.15 & -468.81 & -619.13 \\
\hline & & -1073.52 & -187.03 & -1116.70 & -1427.96 & -125.40 & -126.09 \\
\hline \multirow{2}{*}{$\begin{array}{l}\text { Change In flrst } \\
\text { year cash } \\
\text { flow, 1985s }\end{array}$} & \multirow{2}{*}{$\begin{array}{l}\text { FmHA vs Title vi } \\
T i+l_{e} \mid I-E \text { vs } \\
\text { Title vi }\end{array}$} & -2.72 & 9.83 & -101.30 & -48.41 & -58.45 & -45.08 \\
\hline & & 42.54 & 10.20 & 26.29 & 50.32 & 4.20 & 4.31 \\
\hline \multirow[t]{2}{*}{$\begin{array}{c}\text { Internal rate } \\
\text { of return }\end{array}$} & \multirow{2}{*}{$\begin{array}{c}\text { FmHA vs } T I+l e \text { YI } \\
T i+l e \text { II-E vs } \\
\text { Title Vi }\end{array}$} & 0.27 & 0.28 & 0.17 & 0.22 & 0.16 & 0.19 \\
\hline & & $>1$ & $>1$ & 0.39 & $>1$ & 0.36 & 0.38 \\
\hline
\end{tabular}

Another significant observation is that in Boston, both the MPS and the FmHA standards reduce the life-cycle cost of the site-built home. However, the MPS is less stringent than ASHRAE, while FmHA Title $V$ is more stringent.

Clearly, the ASHRAE standard could be adjusted both to save energy and reduce costs to the consumer, according to these analyses.

Referring to Tables 16 and 17 , it is evident that the selection of a heating fuel has a significant impact on the economics of the conservation investment due to the variation in costs between fuel types. Flectrically heated manufactured homes (Table 17) experience reduced life-cycle cost and positive first-year cash flows in all cities analyzed for both the FmHA and Title II-E standards. In homes heated with gas (Table 16), both standards reduce lifecycle cost in all cities, but the FmHA standard results in negative first-year cash flows in all cities except Phoenix. However, in the worst case, increased monthly expenditures in the first year are less than $\$ 9$. In every case, the internal rate of return is greater than $15 \%$, suggesting that the results are relatively insensitive to reasonable changes in the discount rate. 
Table 17. Summary of Results for Manufactured Homes--Electric Heating

\begin{tabular}{|c|c|c|c|c|c|c|c|}
\hline Characteristics & Standard & $\begin{array}{l}\text { Wash Ington, } \\
\text { D.C. }\end{array}$ & Phoenlx & Minneapolis & Boston & Atlanta & Nashville \\
\hline \multirow{2}{*}{$\begin{array}{l}\text { Change in } \\
\text { energy use, } \\
\text { Mmbtu/yr }\end{array}$} & $\begin{array}{l}\text { FmHA vs } T i+l_{e} \text { vi } \\
T i+l_{\theta} \mid 1-E \text { vs }\end{array}$ & & -15.01 & & -20.93 & -13.82 & \\
\hline & $T i+10 \mathrm{VI}$ & -9.23 & -1.18 & -14.56 & -12.46 & -1.36 & -1.54 \\
\hline \multirow{2}{*}{$\begin{array}{l}\text { Change In } \\
\text { energy use, } \\
\text { kBtu/sq ft/yr }\end{array}$} & $\begin{array}{l}\text { FnHA vs } T I+i e \text { vi } \\
T I+1 \theta 1 \mid-E \text { vs }\end{array}$ & & -13.32 & -46.41 & -23.20 & -15.32 & \\
\hline & $T I+10 \mathrm{VI}$ & -10.23 & -1.31 & -16.14 & -13.81 & -1.51 & -1.71 \\
\hline \multirow{2}{*}{$\begin{array}{c}\text { Change in first } \\
\text { cost, } 19855\end{array}$} & $\begin{array}{l}\text { FmHA vs } T i+I_{e} \text { vi } \\
T i+l e \text { II-E vs }\end{array}$ & 1455.96 & 1334.09 & 2901.91 & 2076.78 & 1735.82 & 1735.82 \\
\hline & $T i+1 e v i$ & 575.09 & 81.64 & 804.45 & 575.09 & 81.64 & 81.64 \\
\hline \multirow{2}{*}{$\begin{array}{l}\text { Change in first } \\
\text { cost, 1985s/ } \\
\text { sq ft }\end{array}$} & $\begin{array}{l}\text { FmHA vs } T I+I_{\theta} \text { VI } \\
T i+I_{e} \mid I-E \text { vs }\end{array}$ & 1.61 & 1.48 & 3.22 & 2.30 & 1.92 & 1.92 \\
\hline & $T i+10 \mathrm{Vi}$ & 0.64 & 0.09 & 0.89 & 0.64 & 0.09 & 0.09 \\
\hline \multirow{2}{*}{$\begin{array}{l}\text { Change in life } \\
\text { cycle cost, } \\
1985 \$\end{array}$} & $\begin{array}{l}\text { FmHA vs } T i+l e \text { VI } \\
T I+l e \mid l-E \text { vs }\end{array}$ & -1738.51 & -2139.54 & -2418.84 & -2041.78 & -1382.04 & -1155.50 \\
\hline & $T I+l a v i$ & -1519.48 & -273.28 & -1841.03 & -1867.18 & -210.51 & -174.76 \\
\hline \multirow{2}{*}{$\begin{array}{l}\text { Change in first } \\
\text { year cash } \\
\text { flow, 1985s }\end{array}$} & $\begin{array}{l}\text { FmHA vs } T I+I_{\theta} V I \\
T I+I_{e} 1 I-E \text { vs }\end{array}$ & 95.03 & 116.76 & 117.08 & 75.98 & 56.53 & 39.82 \\
\hline & $T i t l_{e} V i$ & 107.80 & 18.49 & 135.52 & 124.89 & 14.91 & 12.01 \\
\hline \multirow[t]{2}{*}{$\begin{array}{c}\text { Internal rate } \\
\text { of return }\end{array}$} & $\begin{array}{l}\text { FimHA vs } T i+1 \theta \text { VI } \\
T I+1 \theta \quad I-E \text { vs }\end{array}$ & $>1$ & $>1$ & 0.32 & 0.33 & 0.35 & 0.33 \\
\hline & $T 1+1 \theta \vee 1$ & $>1$ & $>1$ & $>1$ & $>1$ & $>1$ & $>1$ \\
\hline
\end{tabular}





\section{CONCLUSIONS}

This section summarizes the important findings of this initial study. The reader is cautioned that these findings are preliminary and are based on iimited analyses.

\section{FINDINGS FOR SITE-BUILT HOUSING}

Based on the preliminary analysis, the following results are considered important:

- Site-built homes built to ASHRAE Standard 90A-80 represent typical minimum energy conservation design practices.

- Site energy consumption for space conditioning varies by roughly a factor of 4 across the cities analyzed here.

- The FmHA standard results in the lowest energy use; of the three standards compared, the MPS results in the highest energy consumption. Compared to typical minimum building practice, the FmHA standard reduces consumption between about $11 \%$ and $34 \%$, depending on location. The MPS results in consumption increases of $0 \%$ to $16 \%$.

- Compared to typical minimum building practice, the FmHA standard decreases life-cycle cost in the hot and cold cities, but increases it in the temperate cities analyzed here. Whether the variation indicates a climate inequity in the standard has not been determined.

- Compared to typical minimum building practice, the FmHA standard produces negative first-year cash flows in all cities except Phoenix and Roston, where the highest life-cycle cost reductions occur. The negative cash flows do not exceed $\$ 10$ per month.

\section{FINDINGS FOR MANUFACTURED HOUSING}

The following preliminary findings are considered important for manufactured houses. Recause the heating type used in the new manufactured homes in the six cities considered here is split fairly evenly between electric 
resistance and natural gas, this study presents results for each type separately. The following findings refer to gas heating:

- Manufactured homes built to HUD Title VI requirements represent typical minimum energy conservation design practices.

- Site energy consumption for space conditioning varies by approximately a factor of 2.5 across the cities analyzed here.

- The FmHA standard results in the lowest energy consumption of the three standards analyzed; the Title VI standard results in the highest consumption.

- Compared to typical minimum building practice, the FmHA standard reduces annual energy consumption by $36 \%$ to $48 \%$, depending on the location. The Title II-E standard reduces consumption by about $4 \%$ to $23 \%$.

- Compared to typical minimum building practice, both the FmHA standard and the Title II-E standard decrease life-cycle cost.

- Compared to typical minimum building practice, the FmHA standard results in negative first-year cash flows in all cities analyzed except Phoenix. The negative cash flows do not exceed $\$ 9$ per month. The following findings refer to manufactured homes heated by electric resistance:

- Site energy consumption for space conditioning varies by a factor of approximately 2.2 across the cities analyzed.

- Compared to typical minimum building practice, the FmHA standard reduces energy consumption by $37 \%$ to $46 \%$, depending on location. The Title II-E standard reduces consumption by $4 \%$ to $23 \%$.

- Compared to typical minimum building practice, both the FmHA standard and the Title II-E standard reduce 1 ife-cycle cost in all cities analyzed. 
- Compared to typical minimum building practice, both the FmHA standard and the Title II-E standard effect positive first-year cash flows in all cities analyzed here.

In addition to the previous points, this preliminary analysis also suggests the following:

- The net monthly cash flow impacts of the residential building standards analyzed tend to be small, almost always less than $\$ 10$.

- The positive first-year cash flow requirement is a strict test, often causing a homebuyer to forego significant future monetary and energy savings.

- When applied to manufactured housing, the existing site-built FmHA Title $V$ standard does not appear discriminatory. In fact, it produces life-cycle cost reductions more consistently in manufactured homes than in site-built homes in the cities analyzed here.

Again, the reader is cautioned that these findings are preliminary. However, the basic life-cycle cost results appear fairly robust, given that the significant difference in fuel prices between electric resistance and gas heating changes the magnitude, but not the trend, of life-cycle costs for manufactured homes built to different standards. In addition, the internal rate of return on conservation investments in manufactured homes is consistently high for the scenarios considered here, suggesting limited sensitivity to the assumed discount rate.

This imterim report will be followed by a final report that analyzes the FmHA manufactured housing standard (yet to be issued) and compares it to the standards analyzed here. That report will expand the sample of locations analyzed and will address the sensitivity of the results to economic and engineering inputs. 



\section{REFERENCES}

Business Trend Analysts, Inc. 1984. The Mobile Home Industry. Commack, New York.

U.S. Bureau of the Census. 1984. 1984 Statistical Abstract of the United States, 104th ed. U.S. Goverment Printing Office, Washington, D.C.

U.S. Energy Information Administration. 1984a. Housing Characteristics 1982. DOE/EIA-0314(82), Washington, D.C.

U.S. Energy Information Administration. 1984b. Consumption and Expenditures, April 1982 Through March 1983, Part I: National Data. D0E/EIA-0321/1( 82$)$, Washington, D.C. 



\section{DISTRIBUTION}

No. of

Copies

DFFSITE

30 DOE Technical Information Center

10 Jean Boul in

U.S. Department of Energy

Forrestal Building, $\mathrm{GH}-068$

1000 Independence Avenue, SW

Washington, DC 20003

Carl Adams

Tennessee Valley Authority

320 Credit Union Building

Chattanooga, TN 37401

Mike Bell

National Association of Home

Builders

115th M Street NW

Washington, DC 20005

Sydney Berwager

Bonneville Power Administration P.0. Box 3621

Portland, OR 97208

Holt Blomgren

National Manufactured Housing

Federation

1015 15th Street NW

Suite 1240

Washington, DC 20005

Ernie Bonner

Bonneville Power Administration

P.0. Box 3621

Portland, OR 97208

Sheldon Cady

Mineral Insulation

Manufacturers Association

382 Springfield Avenue

Summit, NJ 07901-2782
No. of

Copies

\author{
David Conover \\ National Conference of States \\ on Building Codes and \\ Standards \\ 481 Carlisle Drive \\ Herndon, VA 22070 \\ Rich Davis \\ Farmers' Home Administration \\ 14 th Street Independence \\ Avenue SW \\ Washington, DC 20250 \\ Tom Eckman \\ Northwest Power Planning \\ Council \\ 850 SW Broadway \\ Portland, OR 97205 \\ Mathias Felber \\ Farmers' Home Administration \\ 14th Street Independence \\ Avenue SW \\ Washington, DC 20250 \\ Earl Flanigan \\ Department of Housing and \\ Urban Development \\ 451 7th Street SW \\ Washington, DC 20410 \\ Susan Hickey \\ Bonneville Power Administration \\ P.0. Box 3621 \\ Portland, OR 97208 \\ David Howe \\ Farmers' Home Administration \\ 14 th Street Independence \\ Avenue SW \\ Washington, DC 20250
}


No. of

Copies

Doris Lackey

Masonry Industry Committee

815 15th Street NW

Washington, DC 20005

Jim McCollom

Department of Housing and Urban Development

4517 th Street SW

Washington, DC 20410

Ray McCracken

Farmers' Home Administration

14th Street Independence

Avenue SW

Washington, DC 20250

Rick Mendlen

Department of Housing and

Urban Development

4517 th Street SW

Washington, DC 20410

Evan Mills

Lawrence Berkeley Laboratory

Building 90, Room 3125

Berkeley, CA 94720

Marty Mintz

National Association of Home Builders

115th M Street NW

Washington, DC 20005

Doug Noteware, Commissioner

California Energy Commission

1516 9th Street

Sacramento, CA 95814

Stephen Onisko

Bonneville Power Administration

P.0. Box 3621

Portland, OR 97208

William Pennington

California Energy Commission

1516 9th Street

Sacramento, CA 95814
No. of

Copies

Ted Rauh

California Energy Commission

1516 9th Street

Sacramento, CA 95814

5 John Rivera

9915 Connecticut Avenue

Kensington, MD 20895

Tim Scanlon

Bonneville Power Administration

P.0. Box 3621

Portland, OR 97208

Hoshan Tejuja

Department of Housing and Urban Development.

4517 th Street SW

Washington, DC 20410

Frank Walter

Manufactured Housing Institute

1745 Jefferson Davis Highway

Arlington, VA 22202

Dave Ware

California Energy Commission

1516 9th Street

Sacramento, CA 95814

Phil Windell

Bonneville Power Administration

P.0. Box 3521

Portland, OR 97208

Richard Wright

American Society of Heating, Refrigerating and Air Conditioning Engineers

1791 Tullie Circle NW

Atlanta, GA 30329

ONSITE

DOE Richland Operations Office

D. R. Segna 
No. of

Copies

28 Pacific Northwest Laboratory

R. C. Adams

S. Balistocky

A. A. Bohn

R. M. Fleischman

W. T. Flynn

J. A. Heidell

P. L. Hendrickson

A. D. Lee (5)

S. E. King

R. G. Pratt

R. W. Reilly

R. G. Rivera

Z. T. Taylor (5)

Publishing Coordination MH (2)

Technical Information (5) 
